\title{
ROLE OF ENDOGENIC INTOXICATION IN MUSCLE INJURY IN EXPERIMENT
}

\author{
*V.H. Dzhyvak, O.I. Khlibovska, I.M. Klishch \\ I. HORBACHEVSKY TERNOPIL NATIONAL MEDICAL UNIVERSITY, TERNOPIL, UKRAINE
}

Background. Endogenous intoxication is a multicomponent complex process due to the endogenous biological products or dysfunction of systemic natural detoxification.

Objective. The aim of the research was to study the dynamics of indices of endogenous intoxication in rats with traumatic muscle damage in the experiment.

Methods. The experiment was performed on 45 non-linear white rats, which were modeled with traumatic muscle damage. The level of endogenous intoxication was assessed by the content of medium plasma molecules (MMM), leukocyte and erythrocytic index of intoxication (LII and EII). The research was conducted on the $1^{\text {st }}, 3^{\text {rd }}$, $7^{\text {th }}, 14^{\text {th }}$ days after the injury.

Results. It was found that traumatic muscle damage causes endotoxemia. Manifestations of endogenous intoxication are: the increase of MMM1 in 2.3 times, MMM2 in 2.8 times compare to the intact animals. The level of this indicator slightly decreased in 7 days. Simultaneously with an increase in the MCT level in the post-traumatic period, the total toxic effect on the erythrocyte membrane also increased, which was manifested by a significant increase in EII in all terms of observation.

Conclusions. Traumatic damage of the muscles is accompanied by the growth of molecules of average mass in upto 7 days of observation, which significantly differ from the indicators of the intact group. The results of our research prove that traumatic muscle damage causes endotoxicosis development evidenced by accumulation of endotoxins in the animals' body that is proved by significant changes in endogenous intoxication indices: i.e. erythrocytic and leukocytic indexes of intoxication and content of medium mass molecules.

KEY WORDS: endogenous intoxication; traumatic muscle damage; middle mass molecule.

\section{Introduction}

The increase in injuries all over the world is still one of the topical socio-economic issues of today $[1,3,4]$. Every year in Ukraine, about $10 \%$ of the population gets an injury of varying degrees of severity. Mortality from accidents and injuries in Ukraine increases by an average of $1 \%$ annually [2]. According to the World Health Organization, the traumatic damages are the third among the causes of mortality, and among the population under 40 years - the first. Despite the fact that the patients with polytrauma make up $8-10 \%$ of all inpatient cases, they account for $68 \%$ of fatal cases. According to the data of the European Commission's newsletter in 2019, about five people are seriously injured with consequences in lifethreatening road accidents. Serious injuries are often more expensive for society through longterm rehab and medical needs [1]. At the same time, mortality from accidents and injuries is

*Corresponding author: Dzhyvak V.H., Ph.D. student of the Department of Pathological Physiology, I. Horbachevsky Ternopil National Medical University, Ternopil, Ukraine. E-mail: volodymyrdzh@gmail.com constantly increasing: an average of $1 \%$ annually [2], which is evidence of the ineffectiveness of medical care provided to these patients. Endogenous intoxication is a complex multicomponent process due to the pathological biological activity of endogenous products or dysfunction of systemic natural detoxification $[5,6]$. When the body is injured, there are significant general and local changes that are considered within the traumatic disease [2]. The morphological substrate of traumatic illness is the damage of organs and tissues of various localization and character, which arise with excessive mechanical influence $[2,4]$.

At the moment of injury, tissue elements are destroyed or damaged, receptor fields are changed, and the integrity of blood and lymphatic vessels is violated. Releasing physiologically active substances, in particular, proteolytic enzymes and biogenic amines causes secondary damage. Oxidative stress causes damage to the body of biomacromolecules that leads to accumulation of products of oxidative modification of proteins, degradation of lipid 
components, nucleotides, pigments, and formation of a significant number of middle mass molecules (MMM) [7]. To date, there are three stages of development of the syndrome of systemic inflammatory response: the stage of local production of mediators in response to injury, which can be regarded as a protective response (healing of wounds, protection of cells from pathogenic microorganisms); a stage of ejection of a small number of mediators into the bloodstream to support homeostasis; the stage of generalization of the inflammatory reaction, in which the regulatory systems are not able to provide the homeostasis of the organism [8]. The above mediators exhibit destructive functions, primarily in the system of endothelial cells.

One of the systems of the body that is undergoing significant changes in trauma is the detoxification system. This system dysfunction leads to development of endogenous intoxication syndrome (EIS), which accompanies diseases and complications associated with increased tissue disintegration, increased catabolism, internal organs insufficiency [9]. Markers of endogenous intoxication are molecules of average mass, erythrocyte index of intoxication, which is established and fast in execution $[9,10]$. To date, the age-related mechanisms of the development of endogenous intoxication syndrome is still unclear, there are no perfect pathogenetic approaches to explaining and predicting the early and late effects of traumatic lesions.

\section{Methods}

The experiment was performed on 45 nonlinear white rats, males, weighing 180-200 g, which were kept on a standard vivarium diet. The rats were kept and all experiments were performed following the provisions of the "European Convention for the Protection of Vertebrate Animals Used for Experiments and Other Scientific Purposes" (Strasbourg, 1986); The General Ethical Principles of Animal Experiments adopted by the First National Congress on Bioethics (Kyiv, 2001), the Helsinki Declaration of the World Medical Association (2000).

The animals were divided into 2 groups: 1 - the intact (12 animals), 2 - the controls with traumatic muscle damage (33 animals). The injury was modeled by a dose-fetched foot thigh, equivalent to the animals by the severity of the injury in thiopental-sodium general anesthesia $(40 \mathrm{mg} / \mathrm{kg})$. Animals on the $1^{\text {st }}, 7^{\text {th }}$ (early), $14^{\text {th }}$ (intermediate), $21^{\text {st }}$ (late) days of the post- traumatic period were taken from the experiment. Euthanasia of rats was performed by decapitation under thiopental anesthesia with subsequent total hemorrhaging. The level of endogenous intoxication was assessed by the content of medium-mass molecules in plasma, defining of leukocyte index of intoxication (LII) and erythrocytic indices of intoxication (EII). The content of middle mass molecules was determined in accordance with the method [7]. An acid-soluble fraction was isolated from the blood serum, which was obtained by adding $1.8 \mathrm{ml}$ of a $10 \%$ solution of trichloroacetic acid to $0.2 \mathrm{ml}$ of serum. The middle mass molecules content was determined at wavelengths of 254 (chain amino acids were determined) and $280 \mathrm{~nm}$ (aromatic amino acids were determined), then the coefficient Kc (MMM $280 \mathrm{~nm} / \mathrm{MMM}$ $254 \mathrm{~nm}$ ) was calculated.

The leukocyte index of intoxication is the ratio of blood cell populations that indirectly allows evaluating the predominance of response to pro-or anti-inflammatory cytokines. The leukocyte index of intoxication was determined according to the formula suggested by Ya. KalfKalif in modification by B.A. Reis [10].

Endogenous intoxication was determined by a technique based on the idea of erythrocytes as a universal adsorbent, which allows assessing the level of endogenous intoxication by changing the sorption capacity of erythrocytes of the polar, practically not penetrating through their methylene blue membrane. The amount of absorbed color (in percentages) [7] was calculated using the formula:

$$
A=100-C \times 100 / B \text {, }
$$

where $\mathrm{A}$ - the amount of absorbed dye, \%;

$B$ - the optical density of the initial solution, conditional units of extinction;

C - the optical density of the dye solution after incubation with erythrocytes, conditional units of extinction.

Statistically significant differences between the control and experimental groups were estimated using Mann-Whitney's non-parametric criterion. The differences were considered significant at the probability of a zero hypothesis less than $5 \%(p<0.05)$.

\section{Results}

According to the results of the case study, the MMM1 and MMM2 indices that reflected the content of chain and aromatic amino acids in the medium-sized peptides respectively as well as their decomposition products increased by the $1^{\text {st }}$ day after trauma (Table 1 ). Thus, the 
content of MMM1 in the blood of the affected rats increased in 2.3 times compare to the intact animals. In the same experiment period, the content of MMM2 in rat blood increased accordingly in 2.8 times in relation to the intact animals. The most significant changes in the content of both MMM fractions were observed in 24 hours after the injury. In 7 days after the injury, there was a slight tendency to decrease in the MMM content. Thus, under the influence of the injury, the concentration of blood concentration in both MMM1 and MMM2 was noted. Moreover, the MMM method was more significant for the blank MMM2, indicating the severity of the aromatic amino acids of the average molecule. Since MMMs were the markers of endotoxicosis, the significant changes in their content evidenced the peak of the development and generalization of the syndrome.

The features of MMM are their clearly expressed high biological activity. The accumulation of MMM is not only a marker of endotoxicosis; in the future, they increase the course of the pathological process, acquiring the role of secondary toxins, affecting the livelihoods of all systems and organs. The level of MMM is considered the main biochemical marker, which reflects the level of pathological protein metabolism. It does not only accompany acute and chronic pathology, but is an important factor in their pathogenesis, determines the course and consequences of the disease. According to the results of the research (Table 2), simultaneously with the increase in the MMM level in the post-traumatic period, the total toxic effect on the erythrocyte membrane also increased, which was manifested by a significant increase in endogenous intoxication in all terms of observation.

It is established that the degree of destruction of membranes of erythrocytes during the experiment was the highest. Changes are obviously repeated by the fact that when injuries are caused to the body, energy metabolism and transport of substances in erythrocytes are disturbed, the permeability of their membrane progressively increases.

Based on the analysis of blood cell parameters, the leukocyte index of intoxication was calculated at the beginning of the experiment and in its different terms. As a result of the study, an ambiguous response of the leukocyte relating the pathological processes development was established in a day: the leukocyte index of intoxication increased in 2.7 times (Table 3).

Leukocyte index of intoxication by Ya. CalfCaliph in B.A. Reis modification increased and amounted to $(0.75 \pm 0.01) \%$ on the $7^{\text {th }}$ day of the post-traumatic period and $(0.25 \pm 0.01) \%$ in the control.

\section{Discussion}

According to the case results, MMM1 and MMM2 increased in up to 1 day after trauma. The content of MMM1 in the blood of the affected rats increased in 2.3 times $(0.575 \pm 0.031)$ compare to the intact animals $(0.250 \pm 0.014)$, and the MMM 2 content in the rat blood increased accordingly in 2.8 times $(0.484 \pm 0.011)$

Table 1. Dynamics of the content of medium mass molecules (MMM) in the serum of the rats with traumatic muscle damage $(\mathrm{M} \pm \mathrm{m})$

\begin{tabular}{|c|c|c|c|c|c|}
\hline \multirow{3}{*}{ Indicator } & \multicolumn{5}{|c|}{ Animal groups } \\
\hline & \multirow[b]{2}{*}{$\begin{array}{l}\text { Intact } \\
(n=12)\end{array}$} & \multicolumn{4}{|c|}{ Terms of observation } \\
\hline & & $\begin{array}{l}1^{\text {st }} \text { day } \\
(n=30)\end{array}$ & $\begin{array}{l}7^{\text {th }} \text { day } \\
(n=27)\end{array}$ & $\begin{array}{l}14^{\text {th }} \text { day } \\
(\mathrm{n}=26)\end{array}$ & $\begin{array}{c}21^{\text {st }} \text { day } \\
(\mathrm{n}=25)\end{array}$ \\
\hline MMM1, (conditional units) & $0.250 \pm 0.014$ & $0.575 \pm 0.031 *$ & $0.514 \pm 0.026 *$ & $0.414 \pm 0.026 *$ & $0.341 \pm 0.026 *$ \\
\hline MMM2, (conditional units & $0.173 \pm 0.001$ & $0.484 \pm 0.011 *$ & $0.450 \pm 0.021$ * & $0.350 \pm 0.021 *$ & $0.270 \pm 0.021$ * \\
\hline Coefficient MMM2/ MMM1 & 0.692 & $0.841 *$ & $0.875 *$ & $0.845 *$ & 0.791 \\
\hline
\end{tabular}

Note: * $-p<0,05$ - the probable differences compared with the intact animals.

Table 2. Dynamics of erythrocytic index of intoxication (EII) (\%) in the rat blood (M $\pm \mathrm{m}$ )

\begin{tabular}{|c|c|c|c|c|c|}
\hline \multirow{3}{*}{ Indicator } & \multicolumn{5}{|c|}{ Animal group } \\
\cline { 2 - 6 } & \multirow{2}{*}{$\begin{array}{c}\text { Intact } \\
(n=12)\end{array}$} & \multicolumn{4}{|c|}{ Terms of observation } \\
\cline { 3 - 6 } & $(n=30)$ & $\begin{array}{c}7^{\text {th }} \text { day } \\
(n=27)\end{array}$ & $\begin{array}{c}14^{\text {th }} \text { day } \\
(n=26)\end{array}$ & $\begin{array}{c}21^{\text {st }} \\
(n=25)\end{array}$ \\
\hline (EII) \% & $33.1 \pm 3.8$ & $62.1 \pm 1.1 *$ & $73.5 \pm 8.0 *$ & $47.72 \pm 2.0 *$ & $40.20 \pm 1.0 *$ \\
\hline
\end{tabular}

Note: * $-p<0.05$ - the probable differences compared with the animals of the intact. 
Table 3. Dynamics of leukocyte index of intoxication (\%) in the blood of rats $(M+m)$

\begin{tabular}{|c|c|c|c|c|c|}
\hline \multirow{3}{*}{ Indicator } & \multicolumn{5}{|c|}{ Animal groups } \\
\hline & \multirow{2}{*}{$\begin{array}{l}\text { Intact } \\
(n=12)\end{array}$} & \multicolumn{4}{|c|}{ Terms of observation } \\
\hline & & $\begin{array}{c}24 \text { hours } \\
(n=30)\end{array}$ & $\begin{array}{l}7^{\text {th }} \text { day } \\
(n=27)\end{array}$ & $\begin{array}{l}14^{\text {th }} \text { day } \\
(n=26)\end{array}$ & $\begin{array}{l}21^{\text {st }} \text { day } \\
(n=25)\end{array}$ \\
\hline $\begin{array}{l}\text { Leukocyte index } \\
\text { of intoxication (\%) }\end{array}$ & $0.25 \pm 0.02$ & $0.67 \pm 0.01$ & $0.75 \pm 0.01$ & $0.41 \pm 0.01$ & $0.27 \pm 0.01$ \\
\hline
\end{tabular}

Note: * $-p<0.05$ - the probable differences compared with the animals of the intact.

relative to the intact animals $(0.173 \pm 0.001)$. The most significant changes in the increase of MMM were observed in 24 hours after the injury. In 7 days after the beginning of the experiment, there was a slight tendency to decrease in the content of MMM (MMM1 $0.514 \pm 0.026$, MMM2 $0.450 \pm 0.021$ ). Intoxication syndrome is caused by trauma and is accompanied by increased tissue breakdown, increased catabolic processes, due to the accumulation of excessive amounts of biologically active substances, deformed protein metabolites and other toxic substances of endogenous origin. the results of the research proved that simultaneously with the increase in the MMM level in the posttraumatic period, the total toxic effect on the erythrocyte membrane also increased that was manifested by a significant increase in endogenous intoxication in all terms of observation.

As a result of the research, an ambiguous reaction of the leukocyte response to the development of pathological processes was established in a day: the leukocyte index of intoxication increased in 2.7 times $0.25 \pm 0.02$, and the increase on the $7^{\text {th }}$ day of the post-traumatic period was significant $0.75 \pm 0.01$ compared with the control $0.25 \pm 0.01$. The increase of this indicator may evidence the activation of inflam- matory reactions in the area of traumatic muscle damage and the activation of reparative processes.

\section{Conclusions}

Traumatic damage of the muscles is accompanied by the growth of molecules of average mass up to 7 days of observation, which sig. nificantly differ from the indicators of the intact group. The results of our research indicate that traumatic muscle damage causes endotoxicosis development, which is evidenced by accumulation of endotoxins in the body of animals that is proved by significant changes in endogenous intoxication indices: erythrocyte and leukocyte indexes of intoxication and content of medium mass molecules.

\section{Funding}

This research received no external funding.

\section{Conflict of Interests}

The authors declare no conflict of interest.

\section{Authors Contributions}

Dzhyvak V.H. - Investigation, Formal analysis, writing - original draft; Khlibovska O.I. - investigation, formal analysis, validation, writing original draft; Klishch I.M. - conceptualization, supervision, writing - review and editing.

\section{МАРКЕРИ ЕНДОГЕННОЇ ІНТОКСИКАЦІЇ ПРИ ТРАВМАТИЧНОМУ УРАЖЕННІ М'ЯЗІВ В ЕКСПЕРИМЕНТІ}

В.Г. Дживак, О.І. Хлібовська, І.М. Кліщ ТЕРНОПІЛЬСЬКИЙ НАЦІОНАЛЬНИЙ МЕДИЧНИЙ УНІВЕРСИТЕТ IМЕНІ І.Я. ГОРБАЧЕВСЬКОГО, ТЕРНОПІЛЬ, УКРАЇНА

Вступ. Ендогенна інтоксикація - це складний багатокомпонентний процес, зумовлений патологічною біологічною активністю ендогенних продуктів або дисфункцією систем природної детоксикації, що викликає як загальні, так і локальні зміни.

Мета дослідження. Вивчити динаміку показників ендогенної інтоксикації у щурів з травматичним ушкодженням м'язів. 
Методи дослідження. Експеримент проводили на 45 нелінійних білих щурах. Нанесення травми відбувалося в умовах тіопентало-натрієвого знечулення (40 мг/кг) шляхом дозованого удару по стегну. Рівень ендогенної інтоксикації оцінювали за вмістом молекул середньої маси в плазмі, визначення лейкоцитарного індексу інтоксикації (ЛІІ) і еритроцитарного індексу інтоксикації (ЕІІ). Дослідження проводили на 1, 3, 7, 14 день після травми.

Результати. Було виявлено, що в результаті травматичного ураження м'язів розвивається ендотоксикоз, свідченням чого є накопичення ендотоксинів в організмі тварин. Проявами ендогенної інтоксикації є зростання МСМ1 у 2,3 рази, МСМ2 у 2,8 рази відносно інтактних тварин. Рівень даного показника незначно зменшувався на 7 добу. Одночасно із збільшенням у посттравматичному періоді рівня МСМ, зростав і сумарний токсичний вплив на мембрани еритроцитів, який проявлявся в достовірному підвищенні ЕII у всі терміни спостереження.

Висновки. Травматичне ушкодження м'язів супроводжується зростанням молекул середньої маси до 7 доби спостереження які достовірно відрізняються від контрольних показників. Результати експериментального дослідження свідчать, що при травматичному ушкодженні м'язів розвивається ендотоксикоз, свідченням чого є нагромадження ендотоксинів в організмі тварин, на що вказують виражені зміни показників ендогенної інтоксикації - еритроцитарного та лейкоцитарного індексів інтоксикації та вмісту молекул середньої маси.

КЛЮЧОВІ СЛОВА: ендогенна інтоксикація; травматичне ушкодження мязів; молекули середньої маси.

Відомості про авторів

Дживак Володимир Георгійович - аспірант кафедри патологічної фізіології Тернопільського національного медичного університету імені І.Я. Горбачевського.

Хлібовська Оксана Іванівна - кандидат медичних наук, доцент кафедри акушерствата гінекології ННІПО Тернопільського національного медичного університету імені І.Я. Горбачевського.

Кліщ Іван Миколайович - доктор біологічних наук, професор кафедри функціональної і лабораторної діагностики Тернопільського національного медичного університету імені I.Я. Горбачевського.

Information about the authors

Dzhyvak V.H. - Ph.D. student of the Department of Pathological Physiology, I. Horbachevsky Ternopil National Medical University, Ternopil, Ukraine.

ORCID: 0000-0002-4885-7586, e-mail: volodymyrdzh@gmail.com

Khlibovska O.I. - MD, PhD, Associate Professor of the Obstetrics and Gynecology Department I. Horbachevsky Ternopil National Medical University, Ternopil, Ukraine.

ORCID 0000-0003-3293-0010, e-mail: chlibovska@tdmu.edu.ua

Klishch I.M. - Prof., DSc, PhD, MD Professor of Department of Functional and Laboratory Diagnostics I. Horbachevsky Ternopil National Medical University, Ternopil, Ukraine.

ORCID 0000-0001-6226-4296, e-mail: klishch@tdmu.edu.ua

\section{References}

1. Utriainen R, Pöllänen M, Liimatainen $\mathrm{H}$. Road safety comparisons with international data on seriously injured. Transport policy. 2018 Aug 1;66:138-45.

doi: 10.1016/j.tranpol.2018.02.012

2. Gaiko GV, Derkach RV. Cause analysis and study of the causes of influenza mortality rate in car accidents with injuries to the musculoskeletal system. Science and practice. 2014; 1. 82-6. [In Ukrainian].

3. Baghdadi MB, Tajbakhsh S. Regulation and phylogeny of skeletal muscle regeneration. Developmental biology. 2018 Jan 15;433(2):200-9.

doi: 10.1016/j.ydbio.2017.07.026
4. Yang W, Hu P. Skeletal muscle regeneration is modulated by inflammation. Journal of orthopaedic translation. 2018 Apr 1;13:25-32.

doi: 10.1016/j.jot.2018.01.002

5. Andreichin SM, Holomsha TO. Modern presentations of metabolic endogenous intoxication. Infectious diseases. 2012; 1; 84-87. [In Ukrainian].

6. Bakalyuk OY, Punchyshyn NYa, Dziga SV. Endogenous intoxication syndrome, mechanism of origin, methods of identification. Bulletin of Scientific Research. 2000; 1: 11-3.

7. Karyakina EV, Belova SV. Medium mass molecules as an integral index of metabolic disorders (literature review). Clinic-Lab Diagnostics. 2004; 3: 4-8. 
8. Tidball JG. Inflammatory processes in muscle injury and repair. American Journal of PhysiologyRegulatory, Integrative and Comparative Physiology. 2005 Feb;288(2):R345-53.

doi: 10.1152/ajpregu.00454.2004

9. Speransky I.I., Samoilenko G.E., Lobacheva MV. General analysis of blood - all its possibilities are exhausted? Integral indices of intoxication as criteria for assessing the severity of the course of endogenous intoxication, its complications and the effectiveness of the treatment being performed. The Health of Ukraine. 2009; 6 (19): 51-7. (In Ukrainian).

10. Togaybaev A.A. Kurguzkin A.V., Rikun I.V. Method of diagnosis of endogenous intoxication. Laboratornoe delo. 1988; 9: 22-4. (In Russian).

Received 12 September 2019; revised 19 October 2019; accepted 27 October 2019.

This is open access article distributed under the Creative Commons Attribution License, which permits unrestricted use, distribution, and reproduction in any medium, provided the original work is properly cited. 